\title{
Different effect of nitrogen sources in autotrophic and mixotrophic culture of Scenedesmus sp for biomass and carotenoids production using acidic coal mine drainage effluents
}

INGENIERÍA AMBIENTAL

\section{Efecto de diferentes fuentes de nitrógeno en el cultivo autotrófico y mixotrófico de Scenedesmus sp para la producción de biomasa y carotenoides utilizando efluentes ácidos de drenaje de minas de carbón}

\author{
Néstor Andrés Urbina-Suárez ${ }^{1 \S}$ (i) \\ ${ }^{1}$ Universidad Francisco de Paula Santander, Departamento de Ciencias del Medio Ambiente, Cúcuta, \\ Colombia \\ $\S_{\text {nestorandresus@ufps.edu.co }}$
}

Recibido: 19 de mayo de 2021 - Aceptado: 16 de julio de 2021

\begin{abstract}
In the present study, the conditions for an autotrophic and mixotrophic culture of Scenedesmus sp were established. Effluents from acidic coal mine drains were used to study biomass and carotenoid production, both under autotrophic and mixotrophic conditions in relation to the effect of different sources of nitrogen: sodium nitrate, urea and ammonium phosphate. Pollutant removal was determined, such as COD, TOC, heavy metals, ions and total suspended solids. Batch cultures lasted nine days and biomass production, carotenoids and pollutant removal were compared in each condition. The highest biomass concentration reached was $1.2 \mathrm{~g} / \mathrm{L}$ in the mixotrophic culture with urea, followed by the culture with sodium nitrate of $0.9 \mathrm{~g} / \mathrm{L}$ in a $\mathrm{C} / \mathrm{N}$ ratio of $6: 1$. The highest carotenoid specific concentration was reached in the mixotrophic culture with sodium nitrate, $19.43 \mathrm{mg}$ carotenoids /g biomass. The culture with ammonium phosphate was found to be inhibitory for the growth of the microalgae with the lowest results of all the parameters except for the autotrophic culture where the concentration of carotenoids was very similar to those reached with sodium nitrate and urea. Finally, the mixotrophic culture with urea presented the highest removal percentages, being $86.97 \%$ for total iron, $58.29 \%$ for chlorides and $92.5 \%$ for COD.
\end{abstract}

Keywords: carotenoids, coal mine acid (MAD), mixotrophy, Scenedesmus sp., wastewater. 


\section{Resumen}

En el presente estudio se estableció las condiciones para el cultivo autotrófico y mixotrófico de Scenedesmus sp, utilizando efluentes de drenajes ácidos de mina de carbón con el objeto de estudiar la producción de biomasa y de carotenoides tanto en condiciones autótrofas y mixotróficas en relación con el efecto de diferentes fuentes de nitrógeno: nitrato de sodio, la urea y el fosfato de amonio. Se determinó la remoción de contaminantes como DQO, COT, Metales pesados, iones y Sólidos Suspendidos totales. Los cultivos fueron por lote durante nueve días y se comparó la producción de biomasa, carotenoides y remoción de contaminantes en cada condición. La mayor concentración de biomasa alcanzada fue de $1,2 \mathrm{~g} / \mathrm{L}$ se alcanzó en el cultivo mixotrófico para el medio con urea, seguido por del medio con nitrato de sodio de $0,9 \mathrm{~g} / \mathrm{L}$ en una relación $\mathrm{C} / \mathrm{N}$ de $6: 1$. La mayor concentración específica de carotenoides se alcanzó en el cultivo mixotrófico para el medio con nitrato de sodio y fue de $19.43 \mathrm{mg}$ carotenoides / g biomasa. El medio con fosfato de amonio resultó ser inhibitorio para el crecimiento de la microalga con los resultados más bajos de todos los parámetros con excepción del cultivo autotrófico donde la concentración de carotenoides fue muy similar que las alcanzadas con el medio con nitrato de sodio y urea. Finalmente, el cultivo mixótrófico en el medio con urea presentó los mayores porcentajes de remoción siendo 86,97\% para hierro total, 58,29\% para cloruros y 92,5\% para DQO.

Palabras clave: aguas residuales, carotenoides, drenaje ácido de minas (MAD), mixotrofía, Scenedesmus sp.

\section{Introduction}

Microalgae constitute a very diverse group that are primary producers in aquatic environments, and these photosynthetic microorganisms are useful in applications such as the production of metabolites, in bioremediation ${ }^{(1,2)}$ and as biofertilizers ${ }^{(3)}$. Algae, depending on the species, are capable of growing under different types of trophy (nutrition), autotrophy, heterotrophy and mixotrophy (4-6). Autotrophy is the type of nutrition given in nature through photosynthesis, but its bitechnological development presents technical and physiological difficulties associated with the supply and distribution of light and $\mathrm{CO}_{2}$ (7). Certain microalgae such as those of the genus Chlorella and Scenedesmus can develop heterotrophically, using an organic carbon source ${ }^{(8,9)}$. Heterotrophy allows an increased cell concentration and productivity, but not all the products of interest occur under this nutritional condition. Mixotrophy represents the use of light as an energy source coupled with a simultaneous assimilation of $\mathrm{CO}_{2}$ and organic carbon, therefore, this process can be more efficient to produce biomass as well as some metabolites of interest ${ }^{(10)}$.

The cultivation of microalgae, three key elements are required: 1. a source of carbon (inorganic or organic), 2. a culture medium with sufficient nutrient concentration (nitrogen, phosphorus), and 3. a source of energy, in this case light referred as photosynthetically active radiation ${ }^{(11,12)}$. One drawback of microalgae cultures is the high cost due to the energy required for growth and production of different metabolites of interest ${ }^{(13)}$. In the last years, the technical and economic feasibility has been explored to use sources with a high content of nitrogen $(\mathrm{N})$ and phosphorus $(\mathrm{P})$ such as domestic and industrial wastewater ${ }^{(14,15)}$ as indicated on Table 1.

Coal mine acid drain water (MAD) are characterized by low $\mathrm{pH}$ values and contain dissolved heavy metals such as $\mathrm{Fe}, \mathrm{Mn}, \mathrm{Zn}, \mathrm{Cu}$, $\mathrm{Pb}, \mathrm{Cd}$, among others (16), generate serious negative impacts on the different resources that receive their discharges without prior treatment, mainly on water resources, causing loss of the fauna present, acidification of the resource and decrease in the concentration of oxygen. This problem is caused by mines that do not treat $M A D$, given the high cost of treating these effluents, as well as the lack of technologies that take advantage of these effluents so they could be reincorporated into the process. Some authors have reported the potential of microalgae to grow using MAD, although there is still not much work in this area ${ }^{(22)}$ Therefore, the objective of this 
Table 1. Production of biomass and carotenoids using wastewater.

\begin{tabular}{|c|c|c|c|c|}
\hline Strain & $\begin{array}{c}\text { Type of } \\
\text { wastewater }\end{array}$ & $\begin{array}{l}\text { Biomass } \\
\text { content }\end{array}$ & Carotenoids & Reference \\
\hline Chlorella pyrenoidosa & Olive oil & $2400 \mathrm{mg} / \mathrm{L}$ & $6.1 \mu \mathrm{g} / \mathrm{mg}$ & (16) \\
\hline Dunaliella salina & Dairy industry & $440 \mathrm{mg} / \mathrm{L}$ & $16.8 \mathrm{mg} / \mathrm{L}$ & (17) \\
\hline Spirulina sp. & Domestic & $1080 \mathrm{mg} / \mathrm{L}$ & $3.4 \mu \mathrm{g} / \mathrm{g}$ & (18) \\
\hline Scenedesmus sp. & Domestic & $6.7 \mathrm{~g} / \mathrm{L} / \mathrm{d}$ & $4.06 \mathrm{mg} / \mathrm{g}$ & (19) \\
\hline Botryococcus braunii & Domestic & $2.687 \mathrm{~g} / \mathrm{L}$ & $442 \mathrm{mg} / \mathrm{L}$ & (18) \\
\hline $\begin{array}{c}\text { Chlamydomonas } \\
\text { bioconvexa }\end{array}$ & Vinasse & $222.22 \mathrm{mg} / \mathrm{L}$ & $805.26 \mu \mathrm{g} / \mathrm{g}$ & (20) \\
\hline Micractinium sp. & Vinasse & $177.78 \mathrm{mg} / \mathrm{L}$ & $669.85 \mu \mathrm{g} / \mathrm{g}$ & (18) \\
\hline $\begin{array}{l}\text { Scenedesmus sp. } \\
\text { Consortium: }\end{array}$ & Olive oil mill & $1.8 \mathrm{~g} / \mathrm{L}$ & $92.75 \%$ & (21) \\
\hline $\begin{array}{c}\text { Scenedesmus sp, } \\
\text { Chlorella sp and } \\
\text { Ankistrodesmus s.p }\end{array}$ & DAM & $0.7 \mathrm{~g} / \mathrm{L}$ & N.R & (22) \\
\hline
\end{tabular}

Source: own elaboration

work is to evaluate the effect of three different nitrogen sources under autotrophic and mixotrophic conditions using DAM, generated in a mine in northeastern Colombia, to determine if there is an effect on the production of biomass and carotenoids using Scenedesmus sp.

\section{Methodology}

\subsection{Study organism}

The green algae Scenedesmus sp of the Chlorophyceae class and Chlorococcales order was used, obtained from the INNOVALGAE Laboratory of the Universidad Francisco de Paula Santander (UFPS), Colombia. The inoculum was kept in basal BOLD medium ${ }^{(23)} 1 \mathrm{~g} / \mathrm{L}$ of sucrose was added for the inoculum under mixotrophic condition. The inocula of the autotrophic and mixotrophic conditions were cultured for 20 days in $1 \mathrm{~L}$ photobioreactors $(0.6 \mathrm{~L}$ working volume) under a light intensity of $200 \mu \mathrm{mol} / \mathrm{m}^{2} \mathrm{~s}^{1}$, a photoperiod of $12 \mathrm{~h}$ light/12h dark (12/12 h) and an air flow of $0.6 \mathrm{vvm}$.

\subsection{Culture media and operating conditions}

Undiluted autoclaved MAD was used as medium, which was characterized physiochemically in the Water Laboratory of the UFPS, as established by the method's standard edition 23 (Table 2). Nitrogen sources: sodium nitrate, urea, and ammonium phosphate were evaluated. The nitrate concentration provided by the BOLD medium was calculated and the necessary sucrose concentration was determined for the mixotrophic condition, to maintain a carbon/nitrogen $(\mathrm{C} / \mathrm{N})$ ratio of $6: 1$ for each nitrogen source to be evaluated. The BOLD medium was used as a control for each condition.

The cultures were carried out in $1 \mathrm{~L}$ photobioreactors stirred at $125 \mathrm{rpm}$, an air flow rate of $1 \mathrm{vvm}$, a temperature of $30 \pm 2^{\circ} \mathrm{C}$ and a pH of $7 \pm 0.3$. For the autotrophy and mixotrophy conditions, the light was $200 \mu \mathrm{mol} / \mathrm{m}^{2} \mathrm{~s}^{1}$ provided by fluorescent lamps. An inoculum in exponential phase was used to inoculate the reactor $(10 \%$ of the total operating volume). The photoperiod used was $12 / 12 \mathrm{~h}$. To monitor the different parameters, samples were taken every 24 hours for the 10 days of the process. 
Table 2. Physicochemical parameters measured

\begin{tabular}{|c|c|c|c|}
\hline Parameter & Method & Parameter & Method \\
\hline $\mathrm{COD}(\mathrm{mg} / \mathrm{L})$ & $\begin{array}{c}\text { Standard } \\
\text { Methods 5220C }\end{array}$ & $\mathrm{pH}$ & $\begin{array}{c}\text { Standard Methods } \\
\text { 4500B }\end{array}$ \\
\hline $\mathrm{BOD}(\mathrm{mg} / \mathrm{L})$ & $\begin{array}{c}\text { Standard } \\
\text { Methods } \\
\text { 5210B-4500- } \\
\text { OG }\end{array}$ & Conductivity $(\mu \mathrm{S} / \mathrm{cm})$ & 2510B \\
\hline Nitrates $(\mathrm{mg} / \mathrm{L})$ & Colorimetric & $\begin{array}{l}\text { Total Suspended Solids } \\
\text { (mg /L) }\end{array}$ & $\begin{array}{c}\text { Standard Methods } \\
\text { 2540D }\end{array}$ \\
\hline Nitrites $(\mathrm{mg} / \mathrm{L})$ & Colorimetric & $\begin{array}{c}\text { Heavy Metals } \\
(\mathrm{Pb}, \mathrm{Mn}, \mathrm{Zn}, \mathrm{Ca}, \mathrm{Fe}, \mathrm{Ni}, \\
\mathrm{Cd}, \mathrm{Cr}, \mathrm{Mg}, \mathrm{Cu} \text { y K}) \\
(\mathrm{mg} / \mathrm{L})\end{array}$ & $\begin{array}{c}\text { Standard Methods } \\
\text { 3111D }\end{array}$ \\
\hline $\begin{array}{l}\text { Ammonia nitrogen } \\
(\mathrm{mg} / \mathrm{L})\end{array}$ & Colorimetric & Sulfides (mg/L) & $\begin{array}{c}\text { Standard Methods } \\
4500-\end{array}$ \\
\hline Phosphates (mg/L) & Colorimetric & Chlorides (mg/L) & $\begin{array}{c}\text { Standard Methods } \\
4500-\mathrm{ClB}\end{array}$ \\
\hline
\end{tabular}

Source: own elaboration

\subsection{Analysis Methods}

\subsubsection{Biomass}

For dry weight (DW) biomass quantification, 5 $\mathrm{mL}$ of sample were taken, vacuum filtered on nitrocellulose membranes of $0.22 \mu \mathrm{m}$ pore diameter (Millipore ${ }^{\circledR}$ ) and dried at $80{ }^{\circ} \mathrm{C}$ for $72 \mathrm{~h}$. Previously, these membranes were brought to constant weight by keeping them at $80{ }^{\circ} \mathrm{C}$ for 24 h.

\subsubsection{Pigments and carotenoids}

The pigment specific concentration ( $\mathrm{mg}$ of pigments/g dry biomass) was quantified using a sample volume of $2 \mathrm{ml}$. The samples were centrifuged at $3500 \mathrm{rpm}$ for $10 \mathrm{~min}$ at room temperature. The pellet from each tube was resuspended in $2 \mathrm{ml}$ of acetone $100 \%$ pure. The mixture was vortexed at maximum speed for 10 min. Subsequently, it was centrifuged again at $3500 \mathrm{rpm}$ for $10 \mathrm{~min}$ at room temperature. The supernatant from each tube was removed and added $5 \mathrm{ml}$ with acetone $100 \%$ pure, then read the absorbance at wavelengths: 662, 645 and $470 \mathrm{~nm}$, in a GENESYS 10S UV-Vis spectrophotometer from Thermo brand. The concentration of chlorophyll $a, b$, and total carotenoids was determined according to the Eq.1, 2 y 3 reported by Wellbur ${ }^{(24)}$ :

Chlorophyll $a=\left(15.65 \times A_{662}\right)-\left(7.34 \times A_{645}\right)$

Chlorophyll $b=\left(27.05 \times A_{645}\right)-\left(11.21 \times A_{662}\right)$

Carotenoids $=$

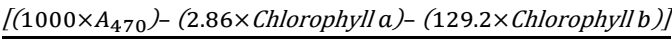

\subsubsection{Nitrogen quantification}

Nitrogen quantification was performed by the brucine method for nitrates (1), the potassium persulfate method and the phenol method for ammonium according to methods standard edition 23. Sucrose concentration was measured by the DNS method. Data were analyzed with NSCC data and SigmaPlot 11 ed. software.

\subsection{Data analysis}

The nitrogen source influence on biomass and carotenoids production was evaluated by an analysis of variance (one-way ANOVA). Post hoc 
tests (LSD test) were used to determine the statistical differences $(\mathrm{P}<0.05)$, $\mathrm{R}$ software 4.0 version for windows was used. The analyzes were carried out in triplicate. Calculations and graphs were performed using the SigmaPlot $11 \mathrm{ed}$.

\section{Results}

\subsection{MAD physicochemical characterization and biomass production under each condition}

Table 3 shows the MAD physicochemical characterization, these are average values obtained during the monitoring time. MAD is known very its acidic $\mathrm{pH}$ values, as evidenced in this work. The average $\mathrm{pH}$ values obtained were $3.59 \pm 0.1$, this can be attributed to the oxidation reactions of $\mathrm{Fe}^{2+}$ to $\mathrm{Fe}^{3+}$ that obtain a higher acid intensity ${ }^{(18,}$ 25). The $\mathrm{pH}$ affects metabolism associated with growth, including ionization of biochemical metabolites, solubility, as well as $\mathrm{CO}_{2}$ bioavailability and assimilation of nutrients, mainly nitrogen. Very acidic $\mathrm{pH}$ can affect this process, so optimum $\mathrm{pH}$ can be in the range of 6 to $8^{(26)}$. The concentrations of COD and BOD show the low concentration of organic matter in the MAD, these effluents contain inorganic compounds, mainly iron salts, sulfur, chlorides, and some heavy metals, which generate extreme environments where only some microorganisms can exist with the ability to assimilate these compounds ${ }^{(19)}$. Also, a low concentration of nitrogen compounds was detected. It is possible that the nitrogen present is rapidly assimilated by the microorganisms present to carry out various metabolic activities, the above evidenced the need to add nitrogen for the biomass and carotenoids production stages.

Figure 1 shows the concentration of ions and heavy metals. The presence of $\mathrm{Ni}, \mathrm{Cd}$ and $\mathrm{Cr}$ was not detected. It was found that the concentrations of $\mathrm{Fe}$ and $\mathrm{Zn}$ are above the permissible discharge value in Colombia, mainly $\mathrm{Fe}$ concentration is considerably high. This can be explained by the chemical characteristics of the soil in the study area, which is clayey and has iron. High iron concentrations can alter the natural balance of ecosystems, it can cause loss of vegetation, desertification, and can impact strongly on the biological component in water sources ${ }^{(20)}$. The remaining parameters are within the permissible limits established, although the high calcium and magnesium concentrations can increase the hardness of the receiving water resource.

Figure 2 shows the biomass production in autotrophy and mixotrophy conditions with each nitrogen source. The highest biomass concentration occurred in autotrophy, it was reached with sodium nitrate $(1.06 \mathrm{~g} / \mathrm{L} \pm 0.06)$, followed by the culture with urea $(0.76 \mathrm{~g} / \mathrm{L} \pm$ 0.04). In the mixotrophic condition, the highest concentration was reached the culture with urea (1.18 g/L \pm 0.0321$)$, followed by the culture with sodium nitrate $(1.1 \mathrm{~g} / \mathrm{L} \pm 0.023)$. For the culture with ammonium phosphate, it was found that growth was low in both conditions, and it was evidenced by the low nitrogen consumption by the microalgae. The assimilation of nitrogen by the culture with sodium nitrate was $100 \%$ in both conditions, the highest assimilation occurs in the first 60 hours. Finally, the cultivation with ammonium phosphate showed low growth in terms of biomass and is corroborated by the low consumption of this nitrogen source.

Various studies have been carried out in order to increase the productivity of microalgae and it has been found that different aspects can limit their growth such as light availability, and the availability and assimilation of nutrients, mainly nitrogen ${ }^{(27,28)}$. This nutrient is what limits growth and carotenoid production. Based on the results, the nitrogen source seems to exert a growth limitation, particularly in the case of ammonium 
Table 3. MAD physicochemical characterization.

\begin{tabular}{cccc}
\hline Parameter & Average value & Parameter & Average value \\
\hline COD $(\mathrm{mg} / \mathrm{L})$ & $185 \pm 0.865$ & Chlorides $(\mathrm{mg} / \mathrm{L})$ & $160.37 \pm 1.4$ \\
BOD $(\mathrm{mg} / \mathrm{L})$ & $128.53 \pm 1.2$ & $\mathrm{pH}$ & $3.59 \pm 0.1$ \\
Nitrates $(\mathrm{mg} / \mathrm{L})$ & $10.23 \pm 0.46$ & $\begin{array}{c}\text { Conductivity } \\
(\mu \mathrm{S} / \mathrm{cm})\end{array}$ & $893.2 \pm 2.5$ \\
& & Total Suspended & \\
Nitrites $(\mathrm{mg} / \mathrm{L})$ & $0.142 \pm 0.04$ & Solids & $3128.4 \pm 3.2$ \\
& $2.5 \pm 0.6$ & Sulfides $(\mathrm{mg} / \mathrm{L})$ & $0.52 \pm 0.02$ \\
Ammonia nitrogen $(\mathrm{mg} / \mathrm{L})$ & $2.81 \pm 0.25$ & & \\
Phosphates $(\mathrm{mg} / \mathrm{L})$ & &
\end{tabular}

Source: own elaboration
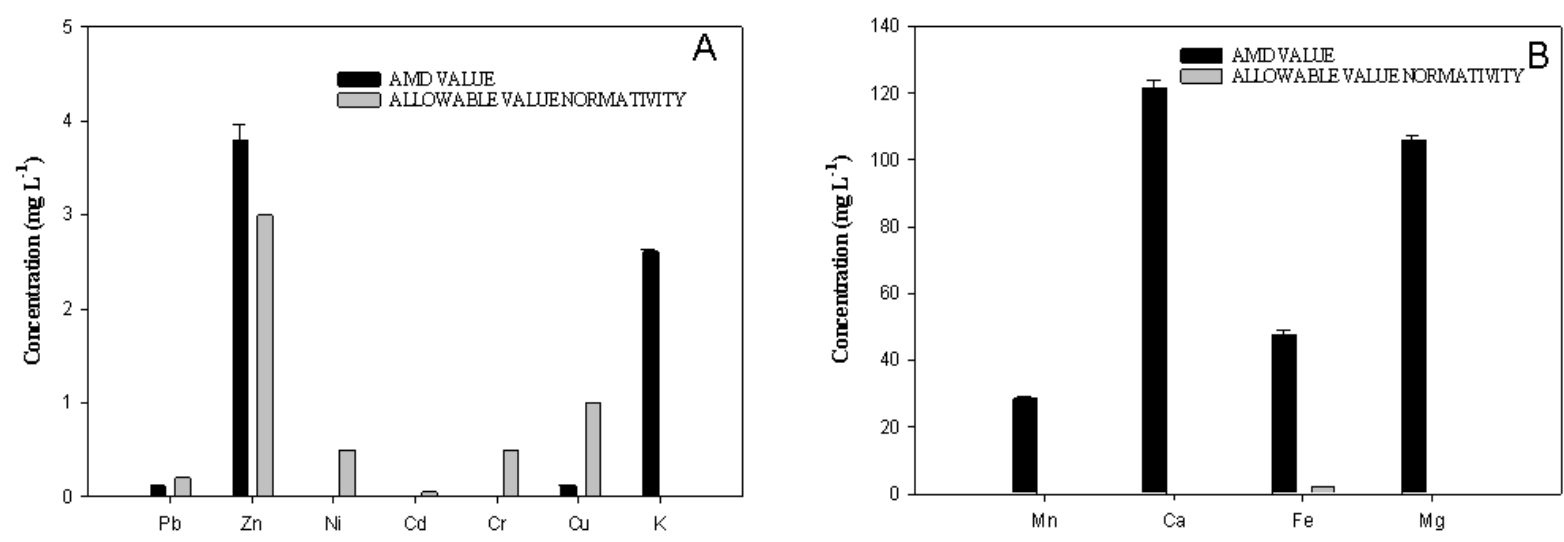

Figure 1. Ions and heavy metals concentrations $(A-B)$ in MAD. Source: own elaboration
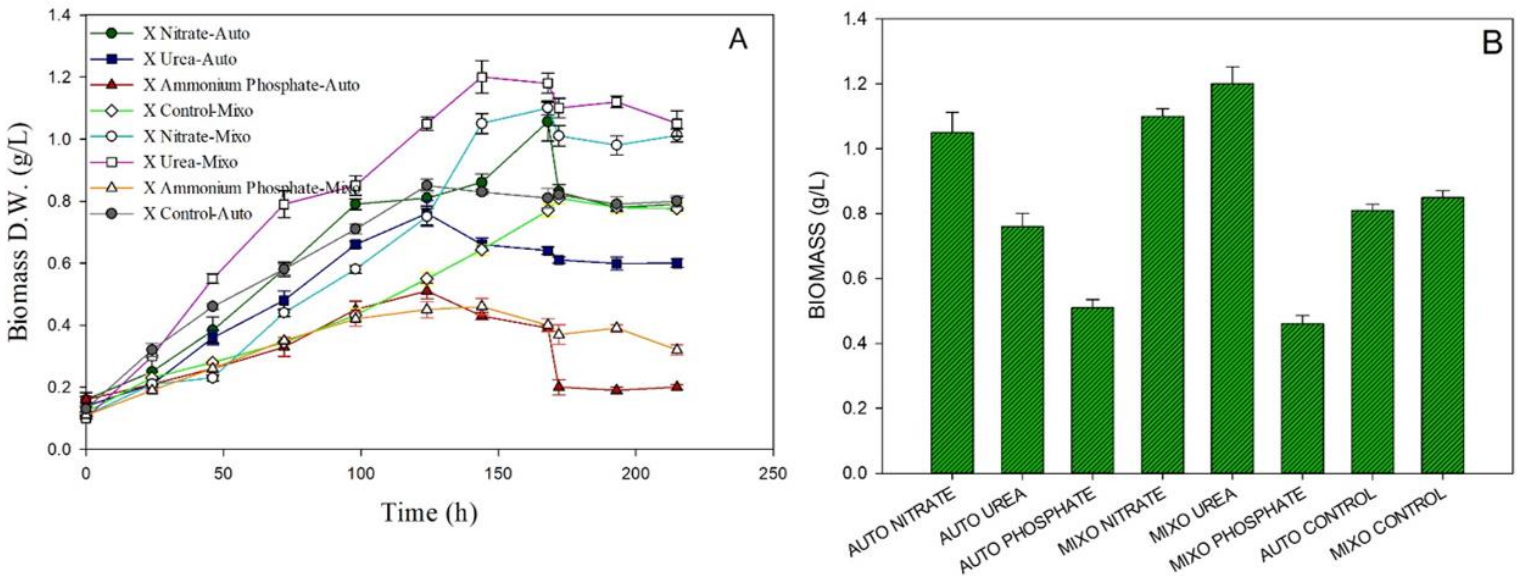

Figure 2. Biomass production on different nitrogen sources using MAD under autotrophic and mixotrophic conditions. A. Growth kinetics and B. Maximum biomass concentration reached. Source: own elaboration 
phosphate. It is possible that it exerts toxicity since it is a neutral molecule and easily crosses the membrane, upsetting the balance in the oxidation-reduction reactions for electron transference, which triggers a mismatch in cellular metabolism ${ }^{(29,30)}$.

\subsection{Carotenoid content in each condition}

Figure 3 shows carotenoid production under autotrophy and mixotrophy conditions with each nitrogen source.

The highest total carotenoid concentration was obtained in the culture with sodium nitrate in mixotrophy (19.53 mg carotenoids/g biomass). The analysis shows that this concentration has significant differences $(\mathrm{P}<0.05)$ when compared to the control in both autotrophic and mixotrophic conditions. In the culture with urea, the carotenoid concentration did not show significant differences when compared the control and the mixotrophic culture $(\mathrm{P}>0.05)$. In the culture with ammonium phosphate, there was a lower carotenoid concentration in both autotrophic and mixotrophic cultures. In the mixotrophic culture, the specific carotenoid concentration was $60 \%$ lower when compared to the autotrophic culture. High nitrogen concentration in the culture medium inhibits the growth and carotenoid production ${ }^{(18)}$, because the enzyme nitrate reductase, which introduces nitrogen to the cell, acts at a higher speed when the concentration of this element are low ${ }^{(31)}$. In the case of ammonium phosphate, the limitation it exerted on the pigment production was $70 \%$. Which can be explained because ammonium unbalances the electrochemical gradient in the thylakoid membrane, which is the organelle where the electron transfer reactions. When this equilibrium is broken, the ATP synthesis in the light phase is affected and, therefore, the reactions of the dark phase are not efficient, thus there is not enough energy for growth and pigment production ${ }^{(32)}$. As observed in the culture with ammonium phosphate and the culture with urea for the mixotrophic condition.

\subsection{Kinetic parameters estimation and nutrient removal}

The specific growth rate of the different cultures was calculated when the cultures were in exponential phase. The pigment concentration shown relates to the maximum pigment concentration reached in each condition. The data obtained are shown in Table 4.

The culture with sodium nitrate had the highest growth rate for the mixotrophic cultures $\left(0.0081 \mathrm{~h}^{-}\right.$ $\left.{ }^{1}\right)$. The lowest growth rates were in the cultures with ammonium phosphate. Regarding the autotrophic culture, the observed rates for the cultures with sodium nitrate and urea were similar. Wang and collaborators ${ }^{(25)}$ reported growth rates in a range of $0.1-0.2 \mathrm{~d}^{-1}$ using DAM under autotrophic conditions and sodium nitrate as nitrogen source, like those achieved in this work, it should be noted that for the other sources and under mixotrophic conditions no data have been reported yet (26). According to the statistical analysis, it was found that the cultures with sodium nitrate and urea do not have significant differences when using DAM, and there are significant differences when compared to the culture with ammonium phosphate, as shown in Table 5. Regarding the control culture (BOLD medium), the cultures with sodium nitrate and urea do present significant differences, evidencing that there is a greater growth rate and carotenoid production using the DAM, when compared to the control culture.

The pollutant removal is shown in Figure 4. It is evidenced that the treatments with the best pollutant removal percentages were the cultures with sodium nitrate and urea. Iron was removed by 98\% under mixotrophic conditions, while under autotrophic conditions, the removal was $92 \%$. Regarding COD and BOD, the removal percentages were $94 \%$ and $98 \%$, respectively, for 


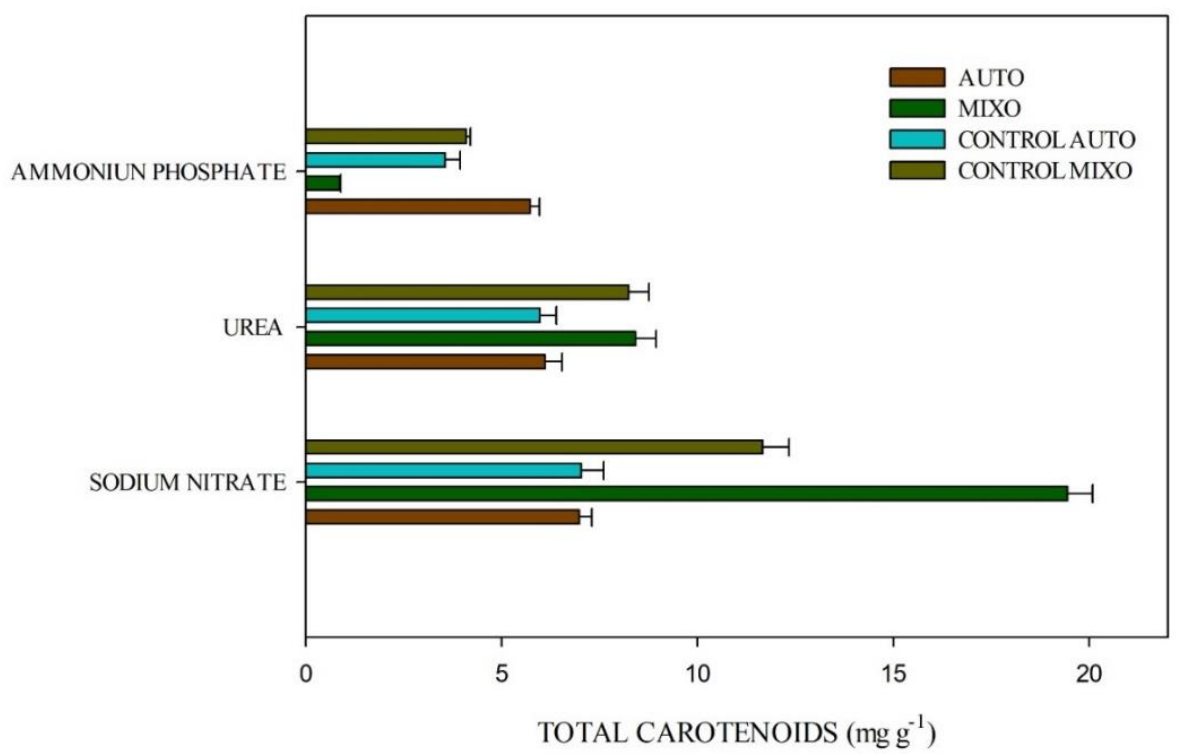

Figure 3. Total carotenoid concentration under autotrophic and mixotrophic conditions with each nitrogen source. Source: own elaboration

Table 4. Kinetic parameters of the Scenedesmus culture in MAD.

\begin{tabular}{ccccc}
\hline Culture & $\begin{array}{c}\text { Nitrogen } \\
\text { source }\end{array}$ & $\begin{array}{c}\text { Biomass productivity } \\
(\mathbf{g} \text { DW } / \mathbf{L} \mathbf{d})\end{array}$ & $\begin{array}{c}\text { Growth rate } \\
\left(\mathbf{h}^{-1}\right)\end{array}$ & $\begin{array}{c}\text { Carotenoid } \\
\text { productivity } \\
\left(\mathbf{m g} / \mathbf{g}^{-} \text {biomass }\right)\end{array}$ \\
\hline \multirow{3}{*}{ Mixotrophy } & Sodium nitrate & $0.183 \pm 1.9 \mathrm{e}^{-4}$ & 0.0081 & $19.45 \pm 6.5 \mathrm{e}^{-2}$ \\
& Urea & $0.2 \pm 1 \mathrm{e}^{-4}$ & 0.0076 & $8.42 \pm 7.2 \mathrm{e}^{-2}$ \\
& $\begin{array}{c}\text { Ammonium } \\
\text { phosphate }\end{array}$ & $0.077 \pm 3.2 \mathrm{e}^{-4}$ & 0.0025 & $0.87 \pm 6 \mathrm{e}^{-3}$ \\
& $\begin{array}{c}\text { Sodium nitrate } \\
\text { Autotrophy }\end{array}$ & $0.151 \pm 4.8 \mathrm{e}^{-5}$ & 0.0054 & $6.98 \pm 3.5 \mathrm{e}^{-4}$ \\
& $\begin{array}{c}\text { Urea } \\
\text { Ammonium } \\
\text { phosphate }\end{array}$ & $0.148 \pm 5.3 \mathrm{e}^{-5}$ & 0.0052 & $6.11 \pm 5.4 \mathrm{e}^{-4}$ \\
& $0.099 \pm 6.1 \mathrm{e}^{-5}$ & 0.0025 & $5.73 \pm 8.6 \mathrm{e}^{-4}$ \\
\hline
\end{tabular}

Source: own elaboration

Table 5. Growth rate statistical analysis of cultures under mixotrophic and autotrophic conditions.

\begin{tabular}{lccccc}
\hline \multicolumn{1}{c}{ Comparison } & Mean Diff & $\mathbf{p}$ & $\mathbf{Q}$ & $\mathbf{P}$ & $\mathbf{P}<\mathbf{0 . 0 5}$ \\
\hline $\mathrm{NO}_{3}$ vs. A.P. & 0.00510 & 4 & 38.052 & $<0.001$ & Yes \\
$\mathrm{NO}_{3}$ vs. CONTROL & 0.00230 & 3 & 17.161 & $<0.001$ & Yes \\
$\mathrm{NO}_{3}$ vs. UREA & 0.000400 & 2 & 2.984 & 0.057 & No \\
UREA vs. A.P. & 0.00470 & 3 & 35.068 & $<0.001$ & Yes \\
UREA vs. CONTROL & 0.00190 & 2 & 14.176 & $<0.001$ & Yes \\
CONTROL vs. A.P. & 0.00280 & 2 & 20.891 & $<0.001$ & Yes \\
\hline
\end{tabular}

A.P.: Ammonium Phosphate. Source: own elaboration 

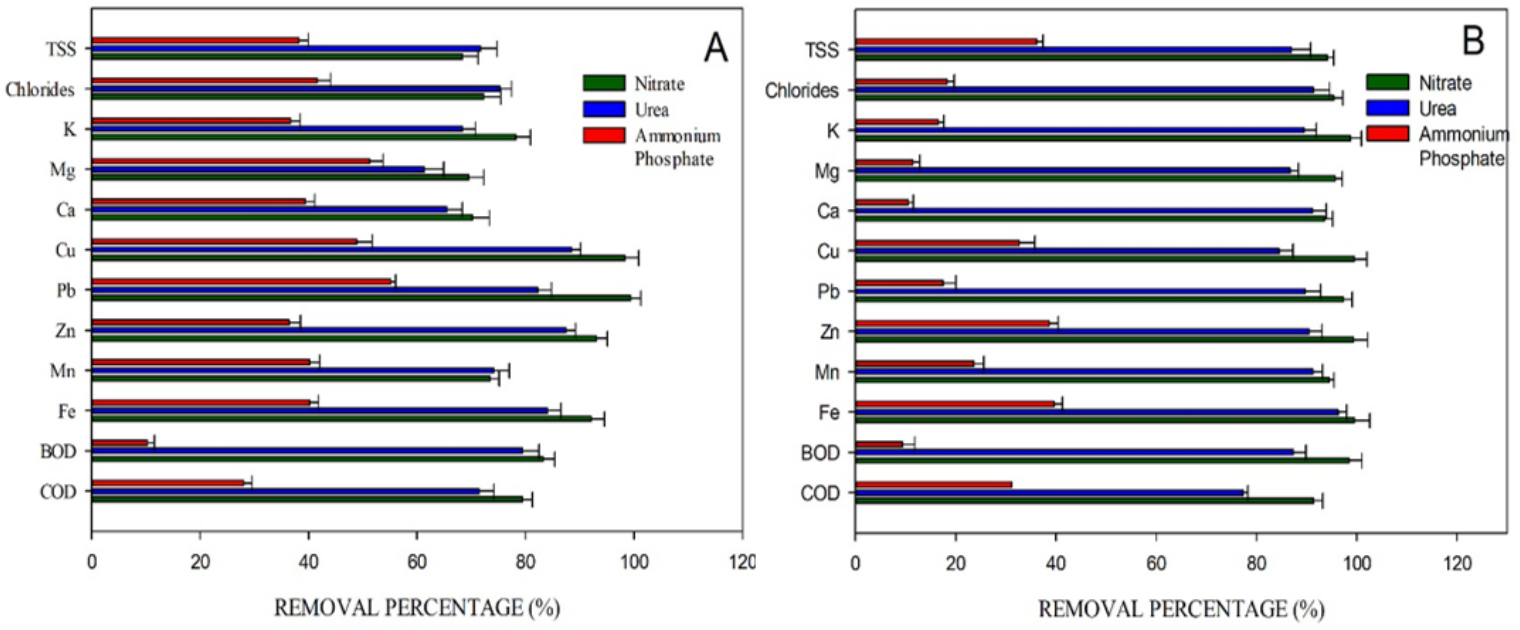

Figure 4. Contaminant Removal A. Autotrophy. B Mixotrophy. Source: own elaboration

sodium nitrate under mixotrophic conditions. For the culture with urea, the removal percentages were between 70 and $80 \%$. For the culture with ammonium phosphate, the removal percentages were low when compared to the other cultures. The values of TSS, chlorides, zinc, iron, BOD, and COD removal percentages measured at the end of the process do not comply with the Colombian regulations for these parameters.

Microalgae have the metabolic capacity to remove iron and heavy metal compounds ${ }^{(22)}$. It has been reported that for microalgae to carry out this process, they follow two mechanisms: absorption (active/passive) and adsorption, mainly through physical adsorption, chemical adsorption and chelation ${ }^{(33)}$. The acidic $\mathrm{pH}$ characteristic of MAD causes the metal ion displacement and complicates absorption and adsorption in the case of microalgae. This phenomenon is solved by the ability of these organisms to alkalize the solution $\mathrm{pH}$, which facilitates ion precipitation. In addition to this, microalgae can act as a selective and absorbent agent for pollutant treatment, managing to remove metals such as $\mathrm{Fe}, \mathrm{As}, \mathrm{Zn}, \mathrm{Mn}, \mathrm{Cd}$ and $\mathrm{Cu}$ and reduce $\mathrm{COD}$ and $\mathrm{BOD}$ concentrations ${ }^{(34) .}$ In this work, similar results were found for the
Scendesmus sp strain, the microalgae managed to alkalize the medium (6.9) for the culture with nitrate and 6.6 for the culture with urea), and, therefore, remove the contaminants. Although in the case of the culture with ammonium phosphate, the $\mathrm{pH}$ only reached values of 5.5 which may explain the low removal and growth in this culture.

\section{Conclusions}

Based on the results, the Scenedesmus sp strain proved to be an attractive alternative for biomass and carotenoid production using DAM in its culture medium. It can grow under the different trophy conditions and the nitrogen sources proposed. Sodium nitrate was the most suitable nitrogen source for biomass production and for carotenoid accumulation under the mixotrophic condition. In the present study, the operating culture conditions under mixotrophy and autotrophy conditions were determined, and obtained the kinetic parameters for each condition, as well as the pollutant removal percentages achieved in the evaluated treatments. This will allow different works in this area, since there are few works reported for this microalga using MAD. 


\section{Acknowledgements and Funding Statement}

To the FINU fund of the Universidad Francisco de Paula Santander for financing the project.

\section{References}

(1) Jaimes-Duarte D-L, Soler-Mendoza W, Velasco-Mendoza J, Muñoz-Peñaloza Y, Urbina-Suárez N-A. Characterization chlorophytas microalgae with potential in the production of lipids for biofuels. CTyF - Ciencia, Tecnología y Futuro. 2012;5(1):93-102. https://doi.org/10.29047/01225383.210

(2) Hussain F, Shah SZ, Ahmad H, Abubshait SA, Abubshait HA, Laref A, et al. Microalgae an ecofriendly and sustainable wastewater treatment option: Biomass application in biofuel and bio-fertilizer production A review. Renew Sustain Energy Rev. 2021;137:110603. https://doi.org/10.1016/j.rser.2020.110603

(3) Solovchenko A, Verschoor AM, Jablonowski ND, Nedbal L. Phosphorus from wastewater to crops: An alternative path involving microalgae. Biotechnol Adv. 2016;34(5):550 64.http://dx.doi.org/10.1016/j.biotechadv. 2016.01.002

(4) Manhaeghe D, Blomme T, Van Hulle SWH, Rousseau DPL. Experimental assessment and mathematical modelling of the growth of Chlorella vulgaris under photoautotrophic, heterotrophic and mixotrophic conditions. Water Res. 2020; $184: 116152$.

https://doi.org/10.1016/j.watres.2020.1161 52

(5) Vidotti ADS, Riaño-Pachón DM, Mattiello
L, Giraldi LA, Winck F V., Franco TT. Analysis of autotrophic, mixotrophic and heterotrophic phenotypes in the microalgae Chlorella vulgaris using time-resolved proteomics and transcriptomics approaches. Algal Res. 2020;51:102060. https://doi.org/10.1016/j.algal.2020.10206 0

(6) Poddar N, Sen R, Martin GJO. Glycerol and nitrate utilisation by marine microalgae Nannochloropsis salina and Chlorella sp. and associated bacteria during mixotrophic and heterotrophic growth. Algal Res. 2018;33:298-309. https://doi.org/10.1016/j.algal.2018.06.002

(7) Kwon G, Le LT, Jeon J, Noh J, Jang Y, Kang D, et al. Effects of light and mass ratio of microalgae and nitrifiers on the rates of ammonia oxidation and nitrate production. Biochem Eng J. 2020;161:107656. https://doi.org/10.1016/j.bej.2020.107656

(8) Scarponi P, Volpi Ghirardini AM, Bravi M, Cavinato C. Evaluation of Chlorella vulgaris and Scenedesmus obliquus growth on pretreated organic solid waste digestate. Waste Manag. 2021;119:235-41. https://doi.org/10.1016/j.wasman.2020.09. 047

(9) Song M, Pei H. The growth and lipid accumulation of Scenedesmus quadricauda during batch mixotrophic/heterotrophic cultivation using xylose as a carbon source. Bioresour Technol. 2018;263:525-31. https://doi.org/10.1016/j.biortech.2018.05. 020

(10) Wang X, Zhang MM, Sun Z, Liu SF, Qin $\mathrm{ZH}$, Mou JH, et al. Sustainable lipid and lutein production from Chlorella mixotrophic fermentation by food waste 
hydrolysate. J Hazard Mater. 2020;400(June):123258.

https://doi.org/10.1016/j.jhazmat.2020.123 258

(11) Ayre JM, Moheimani NR, Borowitzka MA. Growth of microalgae on undiluted anaerobic digestate of piggery effluent with high ammonium concentrations. Algal Res. 2017;24(Part A):218-26. https://doi.org/10.1016/j.algal.2017.03.023

(12) Moheimani NR, Webb JP, Borowitzka MA. Bioremediation and other potential applications of coccolithophorid algae: A review. Algal Res. 2012;1(2):120-33. https://doi.org/10.1016/j.algal.2012.06.002

(13) Cai T, Park SY, Li Y. Nutrient recovery from wastewater streams by microalgae: Status and prospects. Renew Sustain Energy Rev. 2013;19:360-9. https://doi.org/10.1016/j.rser.2012.11.030

(14) Goswami RK, Mehariya S, Verma P, Lavecchia R, Zuorro A. Microalgae-based biorefineries for sustainable resource recovery from wastewater. J Water Process Eng. 2021;40:101747. https://doi.org/10.1016/j.jwpe.2020.10174 7

(15) Feng X, Chen Y, Lv J, Han S, Tu R, Zhou $\mathrm{X}$, et al. Enhanced lipid production by Chlorella pyrenoidosa through magnetic field pretreatment of wastewater and treatment of microalgae-wastewater culture solution: Magnetic field treatment modes and conditions. Bioresour Technol. 2020;306(March):123102. https://doi.org/10.1016/j.biortech.2020.12 3102

(16) Sánchez S, Martínez ME, Espejo MT, Pacheco R, Espinola F, Hodaifa G.
Mixotrophic culture of Chlorella pyrenoidosa with olive-mill wastewater as the nutrient medium. J Appl Phycol. 2001;13(5):443-9. https://doi.org/10.1023/A:1011929723586

(17) Fu W, Wichuk K, Brynjólfssson S. Developing diatoms for value-added products: Challenges and opportunities. $\mathrm{N}$ Biotechnol. 2015;32(6):547-51. https://doi.org/10.1016/j.nbt.2015.03.016

(18) Kalra R, Gaur S, Goel M. Microalgae bioremediation: A perspective towards wastewater treatment along with industrial carotenoids production. J Water Process Eng. 2021;40:101794. https://doi.org/10.1016/j.jwpe.2020.10179 4

(19) Dickinson KE, Whitney CG, McGinn PJ. Nutrient remediation rates in municipal wastewater and their effect on biochemical composition of the microalga Scenedesmus sp. AMDD. Algal Res. 2013;2(2):127-34. http://dx.doi.org/10.1016/j.algal.2013.01.0 09

(20) Santana H, Cereijo CR, Teles VC, Nascimento RC, Fernandes MS, Brunale P, et al. Microalgae cultivation in sugarcane vinasse: Selection, growth and biochemical characterization. Bioresour Technol. 2017;228:133-40. http://dx.doi.org/10.1016/j.biortech.2016.1 2.075

(21) Caprio F Di, Altimari P, Iaquaniello G, Toro L, Pagnanelli F. T.obliquus mixotrophic cultivation in treated and untreated olive mill wastewater. Chem Eng Trans. 2018;64(May):625-30. https://doi.org/10.3303/CET1864105

(22) Torres DD, Cáceres Sepúlveda S, Roa AL, 
Suárez Gelvez JH, Urbina Suárez NA. Utilización de microalgas de la división Chlorophyta en el tratamiento biológico de drenajes ácidos de minas de carbón. Rev Colomb Biotecnol. 2017;19(2):95-104. https://doi.org/10.15446/rev.colomb.biote. v19n2.70429

(23) Cuéllar-García DJ, Rangel-Basto YA, Urbina-Suarez NA, Barajas-Solano AF, Muñoz-Peñaloza YA. Lipids production from Scenedesmus obliquus through carbon/nitrogen ratio optimization. Journal of Physics: Conference Series. 2019;1388:012043. https://doi.org/10.1088/17426596/1388/1/012043

(24) Wellburn AR. The Spectral Determination of Chlorophylls a and b, as well as Total Carotenoids, Using Various Solvents with Spectrophotometers of Different Resolution. J Plant Physiol. 1994;144(3):307-13.

http://dx.doi.org/10.1016/S01761617(11)81192-2

(25) Wang J, Zhang S, He C, She Z, Pan X, Li $\mathrm{Y}$, et al. Source identification and component characterization of dissolved organic matter in an acid mine drainage reservoir. Sci Total Environ. 2020; 739:139732.

https://doi.org/10.1016/j.scitotenv.2020.13 9732

(26) Song C, Han X, Qiu Y, Liu Z, Li S, Kitamura Y. Microalgae carbon fixation integrated with organic matters recycling from soybean wastewater: Effect of $\mathrm{pH}$ on the performance of hybrid system. Chemosphere. 2020;248:126094. https://doi.org/10.1016/j.chemosphere.202 0.126094
(27) Gallardo Martínez D, Bruguera Amarán N, Díaz Duque JA, Cabrera Díaz I. Drenaje ácido de minas y su influencia en ecosistemas asociados al yacimiento Santa Lucía, Cuba. Rev Iberoam Ambient Sustentabilidad. 2020;3(2):67-81. https://doi.org/10.46380/rias.v3i2.79

(28) Arumugam M, Agarwal A, Arya MC, Ahmed Z. Influence of nitrogen sources on biomass productivity of microalgae Scenedesmus bijugatus. Bioresour Technol. 2013;131:246-9. http://dx.doi.org/10.1016/j.biortech.2012.1 2.159

(29) Su Y. Revisiting carbon, nitrogen, and phosphorus metabolisms in microalgae for wastewater treatment. Sci Total Environ. 2021; 762:144590. https://doi.org/10.1016/j.scitotenv.2020.14 4590

(30) Qin L, Liu L, Wang Z, Chen W, Wei D. Efficient resource recycling from liquid digestate by microalgae-yeast mixed culture and the assessment of key gene transcription related to nitrogen assimilation in microalgae. Bioresour Technol. 2018;264(March):90-7. https://doi.org/10.1016/j.biortech.2018.05. 061

(31) Lafarga T, Clemente I, Garcia-Vaquero M. Carotenoids from microalgae. In: Galanakis CM, editor. Carotenoids: Properties, Processing and Applications. Elsevier Inc.; 2020:149-187. Available from: https://doi.org/10.1016/B978-0-12817067-0.00005-1

(32) Gong M, Bassi A. Carotenoids from microalgae: A review of recent developments. Biotechnol Adv. 2016;34(8):1396-412. 
http://dx.doi.org/10.1016/j.biotechadv.201

6.10 .005

(33) Park YT, Lee H, Yun HS, Song KG, Yeom SH, Choi J. Removal of metal from acid mine drainage using a hybrid system including a pipes inserted microalgae reactor. Bioresour Technol. 2013;150:2428.

http://dx.doi.org/10.1016/j.biortech.2013.0 9.136

(34) Krishna Samal DP, Sukla LB, Pattanaik A, Pradhan D. Role of microalgae in treatment of acid mine drainage and recovery of valuable metals. Mater Today Proc. 2020;30(Part 2):346-50. https://doi.org/10.1016/j.matpr.2020.02.16 5 